\title{
Trade and income distribution: Is natural disaster an actor?
}

\author{
Doan Ho Dan Tam ${ }^{*}$, Nguyen Phuc Phuong Vy², Nguyen Thi Xuan Tham ${ }^{3}$, Hoang Thi Ngoc Thang ${ }^{4}$ \\ ${ }^{1}$ Ho Chi Minh City Open University, Vietnam \\ ${ }^{2}$ Institute Of Applied Research And Training Joint Stock Company, Vietnam \\ ${ }^{3}$ University of Economics and Law, Vietnam National University Ho Chi Minh City, Vietnam \\ ${ }^{4}$ Saigon Pharmaceutical Company, Vietnam \\ *Corresponding author: tam.dhd@vnp.edu.vn
}

\begin{tabular}{|c|c|}
\hline ARTICLE INFO & ABSTRACT \\
\hline $\begin{array}{l}\text { DOI: 10.46223/HCMCOUJS. } \\
\text { econ.en.11.1.1328.2021 }\end{array}$ & $\begin{array}{l}\text { This paper examines the impact of trade on household income } \\
\text { inequality (measured using Gini index) under the condition of disaster } \\
\text { (measured using various proxies). The paper uses panel regression on } \\
\text { a balanced dataset of } 48 \text { countries for } 2011-2017 \text { to estimate the }\end{array}$ \\
\hline Received: February $12^{\text {th }}, 2020$ & $\begin{array}{l}\text { impacts, with data combined from World Development Indicators, } \\
\text { World Income Inequality Database, and World Risk Report. Various }\end{array}$ \\
\hline Revised: December 1 1, 2020 & robustness checks are also carried out. The results show that trade \\
\hline Accepted: January $7^{\text {th }}, 2021$ & $\begin{array}{l}\text { does not have any impact on inequality on its own. However, with the } \\
\text { existence of disaster, the increase of trade leads to higher income } \\
\text { inequality. Finally, the effects are stable when disaster is measured }\end{array}$ \\
\hline Keywords: & using Composite index or Vulnerability component but becomes not \\
\hline $\begin{array}{l}\text { trade, income distribution, } \\
\text { inequality, disaster, } \\
\text { vulnerability, panel data }\end{array}$ & $\begin{array}{l}\text { clear when using Exposure component, suggesting that it is } \\
\text { vulnerability the main factor that moderates the impact of trade on } \\
\text { income inequality. }\end{array}$ \\
\hline
\end{tabular}

\section{Introduction}

Income distribution is one of the main themes of economics. It always attracts interest considerable interest among academics and policymakers. On the other hand, globalization in general and trade integration, in particular, has become an irreversible trend nowadays. In this context, it is natural to ask the question of whether the trade has any impact on inequality.

From the theoretical point of view, the trade would increase the well beings and income of a country. However, whether this increase at the aggregated level for the whole country will be distributed to all people, all regions within the country. At this point, the answers seem to vary depending on various things. First, if one takes the Kuznets effect into account, it is expected that inequality would increase assuming the country starts with the low level of income per capita. But after passing the threshold, then the inequality will reduce when income increase. With this mechanism of effect, the impact of trade on income distribution could be beneficial or detrimental depending on the level of income. If a country is at a low level of income, trade leads to an increase in inequality. But if a country's level of income is high enough, which is beyond the threshold in the Kuznets effect, the trade would reduce inequality. Trade theory proposes another route to anticipate the impact of trade on income distribution. If the tradable sector required specific factors, the benefit of trade would only be accumulated to those owning that kind of factor, and the increase of trade would lead to a rise in inequality. Similarly, with the core-periphery model of trade, the benefit of trade is only focused on a few areas, leading to an increase in inequality, at least at the regional level. 
In line with the diversity in the theory aspects, empirical research also finds different results. For example, Cerdeiro and Komaromi (2017) found that trade helps reducing inequality at the household level. On the other hand, Urata and Narjoko (2017), reviewed various empirical studies and concluded that the impact of trade on inequality varies. Some studies at the country level found the association between the increase of trade (measured as a ratio to GDP) and the increase of inequality. However, there are also other country-level studies that did not find a significant impact of trade on inequality. Recently, Hirte, Lessmann, and Seidel (2020) showed that trade increases income inequality (to be precise the inter-regional income inequality), conditioned by the heterogeneity of trade cost.

In this context, this paper examines the impact of trade on household income inequality again, using the most recent data we can collect. We also take the inspiration from Hirte et al. (2020) to put into question the role of disaster as a moderation factor for the impact of trade on income distribution. Using the panel estimation and interaction for moderation effect, enhanced with the robustness check, we find that trade does not have a significant impact on income inequality on its own. However, when disaster presents, trade starts to exert its effects and leads to an increase in inequality. Finally, we also find evidence suggesting that out of various components of disaster, it is the vulnerability rather than the exposure of a country to the disaster that is the main factor that condition the impact of trade on inequality.

\section{Literature review}

This section contains a review of literature relevant to the subject matter includes the theoretical underpinning for the work and empirical research. We focus on three distinct strands of literature on the impact of international trade on inequality and other occasional intermingling factors affecting them.

\subsection{The impact of international trade on inequality}

In this paper, we study the impact of trade liberalization and international trade on household income inequality using the household data survey from World Bank country departments. First, the connection between trade and regional inequality is reviewed. According to the Heckscher-Ohlin model, trade is driven by comparative advantage. However, factors that create the comparative advantage for a country might not be distributed equally among its regions. Consequently, trade benefits only regions with those factors, and an increase in trade would lead to an increase in income inequality between regions. Also, within the framework of standard trade theory, if specific factors exist for trade patterns, increasing trade would benefit only factors being used in trade goods and thus cause the inequality to increase.

Another approach to explain the relationship between trade and inequality comes from spatial economics. According to this approach, the location of economic activities is mainly determined by the benefits and costs of agglomeration and transportation costs. Think of a firm deciding the location of its operation. It would choose to locate in an urban area where many firms form agglomeration if it thinks the benefits of agglomeration in the forms of ease of access (including transportation cost) to sales and procurement networks as well as access to various kinds of information such as information on technology and market outweigh the cost of agglomeration such as traffic congestion and high cost of land, then a firm would locate in an urban area. If the reverse is the case, then a firm would locate in a rural area.

Recognizing the forces toward and against agglomeration, then the question is if globalization increases forces toward or against agglomeration. This depends on various factors, including the kinds of activities promoted by globalization and the location of ports and airports 
(infrastructure), which become gateways to connect domestic economic activities to global economic activities. If globalization leads to an increase in agricultural production, which does not generally gain benefits from agglomeration, then economic activities will spread to rural areas, thus contributing to a reduction in regional inequality. On the other hand, if globalization leads to an increase in manufacturing production, which gains benefits from agglomeration, then economic activities are likely to be clustered in urban areas, contributing to regional inequality.

Although the arguments above focus on inequality between regions, they imply inequality at the household level. Because trade may benefit some areas while leaving others behind, this also widens the household level's income gap when we compare between regions, which would lead to the increase of household income inequality national-wide. Admittedly, one could argue that while trade pushes up between-region inequality for household income level, it would at the same time reduce within-region inequality, leaving the final effect unclear. It is precisely to test this point that this paper replicates the Hirte et al. (2020) study with household income inequality.

The income inequality can be measured in many ways, such as using quintiles to measure income gaps between the poorest and the richest, the Lorenz curve, the Gini coefficient, and the Theil index. In this research, the Gini coefficient is used for representing income inequality. In this research, the Gini coefficient is used for expressing income inequality. Empirically, Kahai and Simmons (2005) also used this index to verify its connection with globalization. They recognize that for developing countries, globalization is positively linked with the growth in inequality, while it is not essential in the case of developed countries. For all countries in their sample, the results indicate that worsening of the globalization index is associated with an increase in income inequality. Anderson (2005) showed that income inequalities within developing countries were increased by openness affects. Furthermore, he indicated that most time-series studies find that greater trading has increased the demand for skilled labor, but most cross-country studies find that greater trade openness has had little impact on overall income inequality. He explains that this discrepancy might be due to the fact that countries selected for time series analysis do not represent the developing world. Also, he argued that its effects via other ways had offset the impact of openness on income inequality via the relative demand for skilled labor.

\subsection{The moderation effects of factors for the impact of trade on inequality}

Besides trade, the direct impact of international trade on inequality, it is also essential to realize the factors which determine it. Most empirical papers study this relationship had heterogeneous results since it depends on many different moderator variables. The standard definition of moderator variable is a variable that affects the direction and/or strength of the relation between an independent or predictor variable and a dependent or criterion variable (Baron \& Kenny, 1986).

Calderon and Chong (2001) studied the external sector and income inequality in interdependent economies. By using a dynamic panel data approach, and showed that the intensity of capital controls, the exchange rate, the type of exports, and the volume of trade affect the longrun distribution of income, their result shows that trade reduces income inequality. However, when interactive dummies are used to verify whether trade openness has a side effect with respect to income inequality depending upon the development, they find that trade openness was positive and barely crucial for industrial countries. It was negative and statistically significant for developing countries. Hirte et al. (2020) found that highly homogeneous countries have no disadvantages from trade with respect to interregional inequality, while trade increases interregional inequality in those countries that are heterogeneous with respect to regional 
differences in international and internal trade costs. They concluded that trade costs are a decisive factor for the impact of international trade on interregional inequality.

In our research, we used the disaster risk that is the factor moderates the effect of trade on inequality. Natural disasters and trade interact in complex, and often unexpected ways, as well as in different dimensions, including at a macro or economy wide level in disaster-affected countries, and at a sectoral, product or firm level. In the framework of the World Risk Index, disaster risk is analyzed as a complex interplay of natural hazards and social, political and environmental factors.

Unlike current approaches that focus strongly on the analysis of the various natural hazards, the World Risk Index, in addition to exposure analysis, focuses on the vulnerability of the population, i.e. its susceptibility, its capacities to cope with and to adapt to future natural events as well as the consequences of climate change. Disaster risk is seen as a function of exposure and vulnerability. The national states are the frame of reference for the analysis. The index consists of indicators in four components: (1) exposure to natural hazards such as earthquakes, storms, floods, droughts and sea-level rise; (2) susceptibility as a function of public infrastructure, nutrition and the general economic framework; (3) coping capacities as a function of governance, medical services and economic security; (4) and adaptive capacities to future natural events and climate change.

According to Clay and Benson (2005), a natural disaster is the occurrence of an extreme or infrequent hazard that affects vulnerable communities or geographic areas, causing substantial damage, disruption, and perhaps casualties and leaving the affected communities unable to function normally. In a study about Adaptive capacity and coping response strategies to natural disasters, Adeagbo, Daramola, Carim-Sanni, Akujobi, and Ukpong (2016) analyzed adverse effects of natural disasters especially as it affected the income, diminished with increasing income brackets. The risks of severe impacts from natural disasters may be reduced as a result of the small scale of operations.

There are other studies showing the relevant result of the disaster risk and interaction. Yang's (2008) model examines the international risk-sharing in the presence of natural disasters. The theory provides arguments for natural disasters to matter for bilateral and multilateral trade and openness. It can be either positive or negative. He reports that hurricanes lead to financial flows into developing countries, helping them to increase imports to buffer income losses. Gassebner, Keck, and Teh (2010), Oh and Reuveny (2010) have observed empirically that natural disasters, such as volcanic eruptions, earthquakes, or storm floods, affect countries' bilateral trade. They also pointed out that disasters are not equally distributed across the globe, and if they occur in a high-income country, the consequences are less fatal, and the number of victims is smaller.

Another issue relates to the resilience of countries against disasters. On the one hand, lessdeveloped countries tend to be more vulnerable against a disaster of a given intensity, for example, with respect to the destruction of infrastructure. On the other hand, high-income countries usually produce more complex products along highly fragmented value-added chains; therefore, a given disaster might cause a more substantial trade shock. However, the net effect is unclear. Felbermayr and Groschl (2013) find out a large disaster increases the affected country's imports by $2 \%$ on average. The effect is stronger if the country is close to a major financial center and may be negative if the country is financially remote. Exports typically fall, but they fall by less if the exporter is financially integrated.

\subsection{The impact of control variables on inequality}

Besides trade, other factors could have an impact on inequality, and they should be 
controlled in the estimation. Consequently, we also investigate the effects of several determinants on regional disparities such as the per capita GDP, the population, the share of arable land on the total surface and resource rents/GDP. By considering interaction terms, one could obtain a much clearer picture of the interplay among all the variables.

The paper most closely related to ours is Hirte et al. (2020). Their result showed that the coefficient of income is positive and significant, the share of arable land is negative and significant, the resource rent variable has no significant effect and the effect of population size is insignificant and does not change the main coefficients. That is in line with Lessmann and Seidel (2017). They also assume that development plays a role in the relationship between trade and inequality, so they use the GDP per capita as a conditioning variable in the interaction term, and they find that in poor countries such as Liberia, Mozambique and Bangladesh, inequalities increased; middle-income countries such as China, Paraguay, and Thailand experience decreasing inequalities; high-income countries such as the U.S. and Germany, experience small decreases of inequality at low levels, whereas rich countries such as Sweden experience (moderately) increasing inequalities. The other variable is the resource variable as resource rents and arable land, whereas resource rents increase regional inequality within countries, lower pressure from land decreases inequality. They also add the transfers variable in the form of development aid tend to increase the concentration of economic activity within countries. This result can be interpreted in two ways. First, aid increases development and therefore, aid-receiving countries move up the upward slope of the Kuznets curve. Second, aid concentrates on single regions of a country, thereby increasing regional inequality. This can hamper the general effectiveness of aid in poor areas, which may also be inhabited by a different ethnicity, engaged in rent-seeking activities or experiencing internal resource conflicts.

Similarly, Lessmann (2013) also found the interaction between FDI with income; whereas FDI does not affect regional inequality in high-income countries, FDI increases regional inequalities in low-income countries. Other works, such as Ezcurra and Rodriguez-Pose (2010), Lessmann (2012), indicated that there is a significant effect for an interaction variable of income and a dummy for countries with a federal constitution. Gennaioli, La Porta, Lopez-de-Silanes, and Shleifer (2013) argued that human capital is the decisive factor for the spread of knowledge in the region; therefore, poor areas have a chance to catch up with wealthier regions, and they found a significant negative coefficient for the education variable. Alesina, Michalopoulos, and Papaioannou (2016) also found a positive relationship between regional inequality and ethnic inequality.

To summary, we can see that: First, there is a possible positive impact of trade on inequality. Increase trade volume could lead to an income disparity increase within a country. Second, this impact of trade on inequality could be conditioned (moderated) by the disaster factor. The higher level of disaster a country exposed would make the impact of trade on inequality increase. These two are the main objectives of our study. However, other factors could affect inequality and need to be controlled while studying the first two effects.

\section{Estimation approach and data}

\subsection{Estimation approach}

Our empirical study takes inspiration from Hirte et al. (2020). However, our study differs from Hirte in the following main points: 1) we study household income inequality, not sub-country regional inequality; 2) we use disaster risk as to the factor that moderates the impact of trade on inequality; and 3) we update our data to recent year. So we propose the model as follows: 


$$
\text { Ginii, } t=\beta 0+\beta 1 \text { Tradei, } t+\beta 2 \text { Tradei, } t * \text { Ri, } t+\beta 3 \mathrm{Ci}, \mathrm{t}+\mu \mathrm{i}, \mathrm{t}
$$

In this model, our dependent variable is Gini coefficient, and we use it as a measure of income inequality at the household level; Tradei,t is an indicator of international trade; Ri,t is the moderator variable that conditions the effect of trade; $\mathrm{Ci}, \mathrm{t}$ are control determinants of inequality; $\mu \mathrm{i}, \mathrm{t}$ is the error term.

In our analysis, we considered the relationship between household income inequality and trade by controlling for income (measured by the log of the per capita GDP) and income squared in all regressions. In addition to checking the robustness of our result, we also considered additional control variables, such as the population, the share of arable land on the total surface, and resource rents/GDP. Details on the variables and income source are given in the appendix.

\subsection{Data collection}

To examine the impact of trade on household income inequality, we used panel data on international trade and household level of income for 48 countries throughout 2011-2017. Thus, our sample sized consists of 336 observations.

We collected the Gini index from the World Bank's World Development Indicators (WDI). To supplement the available data, we used the Gini index from another source which is the United Nations University World Institute for Development Economics Research's (UNU-WIDER's) World Income Inequality Database. We used a measurement of openness to trade as an indicator of international trade, and this data is derived from the World Bank.

In this research, disaster risk was chosen to moderate the relationship between trade and income inequality at the household level, which shows the countries with the lowest risk of natural disasters is the safest country in the world. According to World Risk Report, natural disaster risk is measured in the World Risk Index, calculated by the United Nations University Institute for Environment and Human Security (UNU-EHS) and since 2011 the World Risk Report has been published annually by Bündnis Entwicklung Hilft.

Besides, because World Risk Index is composed of two components: Exposure and Vulnerability, so we also considered each component separately as a moderator. In other words, we try three different (but related) proxies for disaster: World Risk Index, Exposure, and Vulnerability.

\section{Empirical findings}

\subsection{Descriptive statistics}

\section{Table 1}

Summary statistics

\begin{tabular}{lccccc}
\hline \multicolumn{1}{c}{ Variable } & Observations & Mean & Std. Dev & Min & Max \\
\hline Gini (\%) & 336 & 35.83 & 7.93 & 24.00 & 56.2 \\
Trade (\%) & 336 & 96.31 & 55.71 & 23.93 & 408.36 \\
GDP p.c (USD) & 336 & $23,578.97$ & $23,015.18$ & 905.17 & $11,0162.10$ \\
WRI (\%) & 336 & 5.20 & 3.24 & 2.00 & 17.38 \\
Exposure (\%) & 336 & 13.41 & 6.72 & 6.80 & 42.61
\end{tabular}




\begin{tabular}{lccccc}
\hline \multicolumn{1}{c}{ Variable } & Observations & Mean & Std. Dev & Min & Max \\
\hline Vulnerability (\%) & 336 & 37.76 & 8.65 & 20.97 & 57.13 \\
Population (mil) & 336 & 35.79 & 64.90 & 0.51 & 324.98 \\
Arable land (\%) & 336 & 19.45 & 14.21 & 1.42 & 58.90 \\
Resources rent (\%) & 336 & 2.74 & 4.20 & 0.01 & 27.57 \\
\hline
\end{tabular}

Source: Calculated by the authors. See Appendix for more detailed variable definitions and sources

The above table reports the descriptive statistics for the variables which are considered in the analysis. From 2011 to 2017 with 336 observations, the Gini index range from 24\% to 56.2\% and the average value in this sample was $35.8 \%$. There is a wide difference in income inequality between the smallest and highest-income countries. We can also see the large range of trade openness spreads between $23.93 \%$ and $408.36 \%$ and the distributions of trade openness between the countries experience a wide fluctuation through the standard deviation $(55.71 \%)$. With the wide gap of GDP per capita and the high value of standard deviation shown in the above table, we can see the large various average living standards and economic wellbeing when comparing crosscountry in the sample.

The World Risk Index in this sample has a ranking spread from very low (0\%-4\%) to very high $(>10 \%)$ according to World Risk Index report and has the mean value at approximately 5.2\%. The same is true for the average values of two-component variables of WRI: exposure and vulnerability were about $13.5 \%$ and nearly $37.8 \%$, in that order. The wide variation in WRI may be because the natural disaster risk can vary from country to country; it depends on each country's characteristics, such as geography, weather. Next, in three additional control variables, the population mean of 48 nations is around 35.8 million people. The population has spread from about 518 thousand people to 325 million people over the period spread from about 518 thousand people to 325 million people over the period. The arable land has a mean value of above $19 \%$ and ranged between $1.42 \%$ and $58.9 \%$. The resource rent variable's mean value is approximately $2.74 \%$ and ranged from $0.01 \%$ to $27.57 \%$.

\subsection{Estimation results}

We estimate different specifications for the model, and the results are presented in Table 2. The first one consists of only trade and base control variable (logGDPpc and square of $\log$ GDPpc) as independent variables to check the unconditional effect of trade on inequality. Then to check for the moderation effect, we add the interaction between trade and the disaster proxy. For this, we first run a regression model with the World Risk Index moderator to test whether disaster risk has an impact on the relationship between national income inequality and international trade. As shown in the previous section, exposure and vulnerability are the constituent factors of WRI index, so we also further test the regulatory effect of the exposure index and vulnerability index.

For each model, we use the standard approach to select a proper estimator for panel data. First, we use Breusch and Pagan Lagrangian multiplier test for random effects to determine between Pool OLS and Random effect model. In all cases, the test shows the random effect is more appropriate. Then we use the Hausman test to select between Fixed effect and Random effect model. The final result and the corresponding model are presented in Table 2 below.

In column (1), the result of regression without interaction variable to show the 
unconditional relationship between trade and income inequality. We can see that the coefficient of trade is not statistically significant, so the trade variable has no effect on the dependent variable, which is income inequality. This means, on its own, trade does not have any impact on inequality in our sample.

However, in column (2), when we put the moderator variable which is disaster risk in model (1), we see the coefficient of trade has a negative sign, and it is statistically significant which suggests that trade reduces the household income inequality in a country. Moreover, the impact of the interaction variable on the relationship between trade and inequality is shown in this circumstance. To be more precise, the coefficient of the interaction variable (trade_wri) is positive and highly statistically significant at $1 \%$ level, so we can conclude that the disaster risk variable has a positive effect on the relationship we are considering. This means the beneficial effect of trade on reducing inequality will be lower when the disaster index increases. From the results, it could be inferred that after the threshold of disaster index of about $1.7 \%$, the direct beneficial impact of trade will be absorbed totally and trade start causing the increase of inequality. From the descriptive analysis, we can see that the minimum value of the disaster index is $2 \%$, higher than the threshold value mentioned above. Therefore, for our sample, trade always causes inequality to increase, due to the moderation effect of disaster.

\section{Table 2}

Estimation results

\begin{tabular}{lcccc}
\hline & $\mathbf{( 1 )}$ & $\mathbf{( 2 )}$ & $\mathbf{( 3 )}$ & $\mathbf{( 4 )}$ \\
\hline trade & 0.0124 & $-0.0238^{* *}$ & -0.0166 & -0.0289 \\
& $(1.56)$ & $(-2.24)$ & $(-1.31)$ & $(-1.60)$ \\
$\operatorname{logGDPpc}$ & -16.53 & 6.973 & 2.452 & -13.38 \\
& $(-1.17)$ & $(0.68)$ & $(0.24)$ & $(-0.96)$ \\
logGDPpc2 & 0.710 & -0.478 & -0.292 & 0.625 \\
& $(0.93)$ & $(-0.88)$ & $(-0.53)$ & $(0.82)$ \\
trade_wri & & $0.00707 * * *$ & & \\
trade_exp & $(4.06)$ & & \\
& & & $0.00220^{* *}$ & \\
trade_vul & & $(2.39)$ & $0.00110^{* *}$ \\
& & & $(2.55)$ \\
_cons & $126.9 *$ & 12.42 & 38.25 & 104.8 \\
& $(1.97)$ & $(0.26)$ & $(0.79)$ & $(1.62)$ \\
\# Observation & 336 & 336 & 336 & 336 \\
& Fixed Effect & Random Effect & Random Effect & Fixed Effect \\
\hline
\end{tabular}

Note: $\mathrm{t}$ statistics in parentheses, ${ }^{*} \mathrm{p}<10 \%, * * \mathrm{p}<5 \%,{ }^{*} * * \mathrm{p}<1 \%$

Source: Estimated by the authors

In addition to estimating the model with the moderator as the World Risk Index, we also test the effect of the moderator variable of exposure and vulnerability on the relationship between international trade and household income inequality. The results in columns 3 and column 4 show a similar pattern. Trade coefficients alone are not statistically significant, but the interaction terms to capture the moderation effect are significant in both cases. In other words, there is no direct impact of trade on inequality. However, when the disaster exists, trade exposes the impact on inequality, larger trade flow, and higher inequality results.

\subsection{Robustness tests}

To check for robustness of the results. We run the regression with a different combination of control variables and also for different proxies of disaster variable. For each specification, the 
same test procedures to select appropriate models are used. All indicate that only Fixed effect model is appropriate.

Table 3 shows the results of the robustness tests. We used the regression results in Table 2 as the baseline results. The results of estimating income inequality according to the moderator variables, respectively, the world risk index, the exposure index and the vulnerability index are presented in columns (1)-(3).

\section{Table 3}

Robustness tests

\section{Baseline estimates}

Trade $\mathrm{x} R$
(1)

WRI

Trade

$$
-0.0238 * *
$$

$$
0.00707 * * *
$$

(2)

Exposure

$-0.0166$

$0.00220^{* *}$

$-0.0125$

Trade $\mathrm{x} R$

$$
(-1.55)
$$

$$
-0.0182
$$

$$
0.00726^{* * * *}
$$

$$
0.00267 * *
$$

(3) Vulnerability

$-0.0289$

$0.00110 * *$

$$
-0.0347 * *
$$

$0.00135 * * *$

3. Additional controls (arable land, resources rent \% of GDP, population)

Trade

$$
-0.0145
$$

$-0.00196$

$-0.0224$

$$
(-1.12)
$$

Trade $\mathrm{x}$ R

$$
0.00580 * * *
$$

$0.000923 * *$

$$
\text { (1.04) }
$$

$-0.0200$

$0.000805^{*}$

(1.73)

4. All controls (GDP p.c, arable land, resources rent \% of GDP, population)

Trade

Trade $\mathrm{x}$ R
$-0.0136$

$0.00528 * *$

(2.30)
$-0.00362$

0.00124
(0.96)$$
\text { 6) }
$$

Note: $\mathrm{t}$ statistics in parentheses, $* \mathrm{p}<10 \%, * * \mathrm{p}<5 \%, * * * \mathrm{p}<1 \%$, Fixed effect is used for all cases Source: Estimated by the authors

Row (2) gives regression results that we drop the GDP p.c from the list of controls. When using the moderator is the world risk index, the results show the coefficient of trade is insignificant; this is different from the result in baseline regression. Next, the effect of the vulnerability index on the relationship between trade and income inequality is statistically significant and negative, but the baseline result is insignificant.

Row (3) gives regression results that we remove the GDP p.c and add the additional controls (arable land, resources rent \% of GDP, population). The coefficient of trade is not as statistically significant as a result in row (2). Moreover, the regression model with the moderator of the exposure index has no statistically significant. 
Row (4) gives regression results that we use all variables from the list of controls. There is no indication that the trade has any effect on the variable income in all regression models in row (4). Similar to the results in row (3), the exposure index also has no impact on the relationship between trade and income inequality.

The results of robustness tests in the model with word risk index as the interactional variable show that the coefficient of trade has no statistically significant, which was different from the results in baseline estimates. Besides, there is also a difference compared with the baseline result, which is the exposure index does not moderate the relationship between trade and household income inequality. In the estimates using vulnerability index, there is only a regression model that drops the control variable of GDP p.c results trade hurts the income inequality. Finally, the causal impact of trade openness on household income inequality is interacted by two different moderators-disaster risks and vulnerability-in all cases happening in this test.

Putting all the things together, the results from the robustness check show two interesting implications. First, the direct impact of trade alone is almost not existent, but under the presence of disaster, trade causes inequality to increases. Second, when disaster is proxied by vulnerability or composite index (WRI), the moderation effects are relatively clear and stable while the effect is not stable if exposure is used as a proxy for disaster.

\section{Conclusions}

The primary objective in this paper is whether disaster risk, which is the moderation variable, affects the association between trade and household income inequality. We use the balanced dataset of 48 countries for the 2011-2017 period to consider this problem. Note that we investigate the income inequality at the household level and use the trade openness in the relationship between two variables.

There are several findings we can conclude through this research. Firstly, the empirical result does not show the causal relationship between trade and household income inequality without the moderator variable. Secondly, we find that disaster risk moderates the causal effect of trade on income inequality. Overall, it is the condition for the impact of trade on inequality to exist. Third, this moderation effect remains when the moderator variable was replaced by other moderator terms which are exposure and vulnerability. Thirdly, when we change some control variables in the model, the results are still consistent with the moderator variables are composite disaster risk and vulnerability while the effect is unstable exposure are used. Since composite disaster risk consists of vulnerability and exposure, the results hint at an interesting suggestion: It is vulnerability an important factor that moderates and conditions the impact of trade on inequality.

There are some limitations to our study. Firstly, the reason why we cannot cover all data over the world is the missing of data from the sources we can access, so we just select 48 countries in the available dataset to create the sample in our research. Secondly, it is difficult for us to complete this paper perfectly, we know that the possibility of endogeneity in our model may exist, as Hirte et al. (2020) argued. But we cannot cover it in this paper due to the limitation of data.

\section{References}

Adeagbo, A., Daramola, A., Carim-Sanni, A., Akujobi, C., \& Ukpong, C. (2016). Effects of natural disasters on social and economic well-being: A study in Nigeria. International Journal of Disaster Risk Reduction, 17(C), 1-12. 
Alesina, A., Michalopoulos, S., \& Papaioannou, E. (2016). Ethnic inequality. Journal of Political Economy, 124(2), 428-488.

Anderson, E. (2005). Openness and inequality in developing countries: A review of theory and recent evidence. World Development, 33(7), 1045-1063.

Baron, R. M., \& Kenny, D. A. (1986). The moderator-mediator variable distinction in social psychological research: Conceptual, strategic, and statistical considerations. Journal of Personality And Social Psychology, 51(6), 1173-1182.

Calderon, C., \& Chong, A. (2001). External sector and income inequality in interdependent economies using a dynamic panel data approach. Economics Letters, 71(2), 225-231.

Cerdeiro, D. \& Komaromi, A. (2017). The effect of trade on income inequality: A cross-sectional approach. Washington, DC: International Monetary Fund.

Clay, E., \& Benson, C. (2005). Aftershocks: Natural disaster risk and economic development policy. Retrieved November 11, 2020, from http://www.odi.org.uk/publications/briefing/bp_disasters_nov05.pdf

Day, T. F. S. J., \& Himmelsbach, J. (2019). World risk report 2019. Retrieved November 12, 2020, from https://www.weforum.org/reports/the-global-risks-report-2019

Ezcurra, R., \& Rodríguez-Pose, A. (2010). Does decentralization matter for regional disparities? A cross-country analysis. Journal of Economic Geography, 10(5), 619-644.

Felbermayr, G., \& Gröschl, J. (2013). Natural disasters and the effect of trade on income: A new panel IV approach. European Economic Review, 58(1), 18-30.

Gassebner, M., Keck, A., \& Teh, R. (2010). Shaken, not stirred: The impact of disasters on international trade. Review of International Economics, 18(2), 351-368.

Gennaioli, N., La Porta, R., Lopez-de-Silanes, F., \& Shleifer, A. (2013). Human capital and regional development. The Quarterly Journal of Economics, 128(1), 105-164.

Hirte, G., Lessmann, C., \& Seidel, A. (2020). International trade, geographic heterogeneity and interregional inequality. European Economic Review, 127(C), 1-23.

Kahai, S. K., \& Simmons, W. (2005). The impact of globalization on income inequality. Global Business and Economics Review, 7(1), 1-15.

Lessmann, C. (2012). Regional inequality and decentralization: An empirical analysis. Environment and Planning A, 44(6), 1363-1388.

Lessmann, C. (2013). Foreign direct investment and regional inequality: A panel data analysis. China Economic Review, 24(C), 129-149.

Lessmann, C., \& Seidel, A. (2017). Regional inequality, convergence, and its determinants - A view from outer space. European Economic Review, 92(1), 110-132.

Oh, C. H., \& Reuveny, R. (2010). Climatic natural disasters, political risk, and international trade. Global Environmental Change, 20(2), 243-254.

Urata, S., \& Narjoko, D. A. (2017). International trade and inequality. Retrieved November 13, 2020, from Asian Development Bank Institute website: https://www.adb.org/publications/international-trade-and-inequality

World Bank. (2020). World development indicators. Retrieved September 8, 2020, from https://datacatalog.worldbank.org/dataset/world-development-indicators 
Yang, D. (2008). Coping with disaster: The impact of hurricanes on international financial flows, 1970-2002. The BE Journal of Economic Analysis \& Policy, 8(1), 1-45.

\section{APPENDIX}

\section{Description of variables and source of data}

\begin{tabular}{|c|c|c|c|c|}
\hline No. & $\begin{array}{c}\text { Variable } \\
\text { name }\end{array}$ & Unit & Variable description & Source \\
\hline 1 & GINI index & $\%$ & $\begin{array}{l}\text { Gini index measures the extent to } \\
\text { which the distribution of income (or, } \\
\text { in some cases, consumption } \\
\text { expenditure) among individuals or } \\
\text { households within an economy } \\
\text { deviates from a perfectly equal } \\
\text { distribution. A Lorenz curve plots } \\
\text { the cumulative percentages of total } \\
\text { income received against the } \\
\text { cumulative number of recipients, } \\
\text { starting with the poorest individual } \\
\text { or household. The Gini index } \\
\text { measures the area between the } \\
\text { Lorenz curve and a hypothetical line } \\
\text { of absolute equality, expressed as a } \\
\text { percentage of the maximum area } \\
\text { under the line. Thus, Gini index of } \\
0 \text { represents perfect equality, while } \\
\text { an index of } 100 \text { implies perfect } \\
\text { inequality. }\end{array}$ & $\begin{array}{l}\text { World Bank's World Development } \\
\text { Indicators } \\
\text { United Nations }\end{array}$ \\
\hline 2 & $\begin{array}{c}\text { Trade }(\% \text { of } \\
\text { GDP) }\end{array}$ & $\%$ & $\begin{array}{l}\text { Trade is the sum of exports and } \\
\text { imports of goods and services } \\
\text { measured as a share of gross } \\
\text { domestic product. }\end{array}$ & $\begin{array}{l}\text { World Bank national accounts data, } \\
\text { and OECD National Accounts data } \\
\text { files. }\end{array}$ \\
\hline 3 & $\begin{array}{l}\text { GDP per } \\
\text { capita } \\
\text { (constant } \\
2010 \text { US\$) }\end{array}$ & US\$ & $\begin{array}{l}\text { GDP per capita is gross domestic } \\
\text { product divided by midyear } \\
\text { population. GDP is the sum of gross } \\
\text { value added by all resident producers } \\
\text { in the economy plus any product } \\
\text { taxes and minus any subsidies not } \\
\text { included in the value of the products. } \\
\text { It is calculated without making } \\
\text { deductions for depreciation of } \\
\text { fabricated assets or for depletion and } \\
\text { degradation of natural resources. } \\
\text { Data are in constant } 2010 \text { U.S. } \\
\text { dollars. }\end{array}$ & $\begin{array}{l}\text { World Bank national accounts data, } \\
\text { and OECD National Accounts data } \\
\text { files. }\end{array}$ \\
\hline 4 & $\begin{array}{l}\text { Population, } \\
\text { total }\end{array}$ & People & $\begin{array}{l}\text { Total population is based on the de } \\
\text { facto definition of population, which } \\
\text { counts all residents regardless of }\end{array}$ & \begin{tabular}{|lll} 
(1) United Nations & Population \\
Division. & World & \multicolumn{2}{c}{ Population } \\
Prospects: & 2019 & Revision. (2) \\
\end{tabular} \\
\hline
\end{tabular}




\begin{tabular}{|c|c|c|c|c|}
\hline & & & $\begin{array}{l}\text { legal status or citizenship. The values } \\
\text { shown are midyear estimates. }\end{array}$ & $\begin{array}{l}\text { Census reports and other statistical } \\
\text { publications from national } \\
\text { statistical offices, (3) Eurostat: } \\
\text { Demographic Statistics, (4) United } \\
\text { Nations Statistical Division. } \\
\text { Population and Vital Statistics } \\
\text { Report (various years), (5) U.S. } \\
\text { Census Bureau: International } \\
\text { Database, and (6) Secretariat of the } \\
\text { Pacific Community: Statistics and } \\
\text { Demography Programme. }\end{array}$ \\
\hline 5 & $\begin{array}{l}\text { Arable land } \\
\text { (\% of land } \\
\text { area) }\end{array}$ & $\%$ & $\begin{array}{l}\text { Arable land includes land defined by } \\
\text { the FAO as land under temporary } \\
\text { crops (double-cropped areas are } \\
\text { counted once), temporary meadows } \\
\text { for mowing or for pasture, land } \\
\text { under market or kitchen gardens, and } \\
\text { land temporarily fallow. Land } \\
\text { abandoned as a result of shifting } \\
\text { cultivation is excluded. }\end{array}$ & $\begin{array}{l}\text { Food and Agriculture } \\
\text { Organization, electronic files and } \\
\text { web site. }\end{array}$ \\
\hline 6 & $\begin{array}{l}\text { Total natural } \\
\text { resources } \\
\text { rents }(\% \text { of } \\
\text { GDP) }\end{array}$ & $\%$ & $\begin{array}{l}\text { Total natural resources rents are the } \\
\text { sum of oil rents, natural gas rents, } \\
\text { coal rents (hard and soft), mineral } \\
\text { rents, and forest rents. }\end{array}$ & $\begin{array}{l}\text { Estimates based on sources and } \\
\text { methods described in "The } \\
\text { Changing Wealth of Nations: } \\
\text { Measuring Sustainable } \\
\text { Development in the New } \\
\text { Millennium" (World Bank, 2011). }\end{array}$ \\
\hline 7 & $\begin{array}{l}\text { World Risk } \\
\text { Index }\end{array}$ & $\%$ & $\begin{array}{l}\text { WRI is calculated on a country-by- } \\
\text { country basis through the } \\
\text { multiplication of exposure and } \\
\text { vulnerability. }\end{array}$ & $\begin{array}{l}\text { The World Risk Report has been } \\
\text { published annually } \\
\text { by Bündnis Entwicklung Hilft } \\
\text { http://weltrisikobericht.de/english/ }\end{array}$ \\
\hline 8 & $\begin{array}{l}\text { Exposure } \\
\text { Index }\end{array}$ & $\%$ & $\begin{array}{l}\text { Exposure covers threats of the } \\
\text { population due to earthquakes, } \\
\text { storms, floods, droughts and sea- } \\
\text { level rise. }\end{array}$ & $\begin{array}{l}\text { The World Risk Report has been } \\
\text { published annually } \\
\text { by Bündnis Entwicklung Hilft } \\
\text { http://weltrisikobericht.de/english/ }\end{array}$ \\
\hline 9 & $\begin{array}{l}\text { Vulnerability } \\
\text { Index }\end{array}$ & $\%$ & $\begin{array}{l}\text { Vulnerability encompasses the } \\
\text { societal sphere and is comprised of } \\
\text { three components, which are } \\
\text { weighted equally in the calculation: } \\
\text { susceptibility, coping, and } \\
\text { adaptation }\end{array}$ & $\begin{array}{l}\text { The World Risk Report has been } \\
\text { published annually } \\
\text { by Bündnis Entwicklung Hilft } \\
\text { http://weltrisikobericht.de/english/ }\end{array}$ \\
\hline
\end{tabular}

